\title{
PENGARUH DISIPLIN, LINGKUNGAN ORGANISASI DAN LOYALITAS TERHADAP KINERJA PEGAWAI DINAS KESEHATAN KABUPATEN ACEH TAMIANG
}

\author{
Afrinalda \\ Universitas Islam Sumatera Utara \\ afri.nalda@gmail.com
}

\begin{abstract}
The formulation of this research is whether there is an influence of discipline, environment and loyalty work to the performance of officers in the health Department of Aceh Tamiang District, and the purpose of this research is to know and analyze the influence of discipline, Environmental organization and loyalty to the performance of officers in the Health office of Aceh Tamiang District. The method used in this research is the method of quantitative scriptive analysis using multiple linear regression with the measurement of Likert scale. The samples used in this study amounted to 33 employees. The results showed that simultaneously the variable discipline, organizational environment, loyalty has significant effect on performance with a significance value of $0.001 \mathrm{~B}$. The discipline has a significant impact on the performance of officers at the Aceh Tamiang District health Office with significance value of 0.000. The organizational environment has a significant effect on the performance of employees at the Aceh Tamiang District Health Department with significance value of 0.000. Further, the work loyalty has a significant effect on the performance of officers in Aceh Tamiang District Health Department with significance value of 0.000 Simultaneously
\end{abstract}

Keywords: discipline, organizational environment, loyalty

ABSTRAK : Rumusan penelitian ini adalah apakah ada pengaruh Disiplin, Lingkungan Organisasi dan Loyalitas kerja terhadap Kinerja Pegawai di Dinas Kesehatan Kabupaten Aceh Tamiang, dan tujuan penelitian ini adalah untuk mengetahui dan menganalisis pengaruh Disiplin, Lingkungan Organisasi dan Loyalitas kerja terhadap Kinerja Pegawai di Dinas Kesehatan Kabupaten Aceh Tamiang. Metode yang digunakan pada penelitian ini adalah metode analisis diskriptif kuantitatif dengan menggunakan regresi linear berganda dengan pengukuran skala likert. Sampel yang dipakai pada penelitian ini berjumlah 33 orang pegawai. Hasil penelitian menunjukkan bahwa secara serempak variable Disiplin, Lingkungan Organisasi, Loyalitas berpengaruh signifikan terhadap Kinerja dengan nilai signifikansi sebesar $0.001^{b}$. secara parsial, disiplin berpengaruh signifikan terhadap Kinerja Pegawai di Dinas Kesehatan Kabupaten Aceh Tamiang dengan nilai signifikansi sebesar 0.000. lingkungan Organisasi berpengaruh signifikan terhadap Kinerja Pegawai di Dinas Kesehatan Kabupaten Aceh Tamiang dengan nilai signifikansi sebesar 0.000. selanjutnya loyalitas kerja berpengaruh signifikan terhadap Kinerja Pegawai di Dinas Kesehatan Kabupaten Aceh Tamiang dengan nilai signifikansi sebesar 0.000

Secara simultan,

Kata Kunci : Disiplin, lingkungan organisasi, loyalitas

\section{Pendahuluan}

Sumber daya manusia penting karena berperan untuk menggerakkan sumber daya lainnya untuk mencapai tujuan organisasi.Di dalam pengelolahan SDM, apabila individu dalam organisasi yaitu sumber daya manusianya dapat berjalan efektif maka organisasi juga dapat berjalan efektif. Beberapa kegiatan pengelolahan SDM misalnya pengadaan, penilaian, perlindungan, memotivasi pegawai, memberdayakan pegawai, peningkatan disiplin, bimbingan,loyalitas pegawai dll. Pengelolaan dan pengoptimalan sumber daya manusia tidak lepas dari faktor pegawai.Organisasi harus mempunyai pegawai mempunyai kinerja yang baik. Dengan kata lain 
kelangsungan suatu organisasi ditentukan oleh kinerja pegawainya (Wirawan, 2012:123).

Kinerja merupakan suatu fungsi kemampuan pekerja dalam menerima tujuan pekerjaaan, tingkat pencapain tujuan dan interaksi antara tujuan dan loyalitas pegawai. (Dewi, 2012) kinerja sebagai hasil kerja seseorang atau sekelompok orang dalam suatu organisasi dengan wewenang dan tanggung jawab masingmasing dalam upaya mencapai tujuan organisasi secara legal, tidak melanggar hukum, dan sesuai dengan moral dan etika. Kinerja pegawai adalah yang mempengaruhi seberapa banyak mereka memberi kontribusi kepada organisasi atau perbaikan kinerja baik untuk individu maupun kelompok menjadi pusat perhatian dalam upaya meningkatkan kinerja organisasi. (Ridwan, 2013)

Dari beberapa faktor diatas, untuk meningkatkan kinerja pegawai salah satunya adalah dengan memperhatikan faktor lingkungan Organisasi selaku induk kerja harus menyediakan lingkungan organisasi yang aman, nyaman dan kondusif dapat bersinergi antara satu divisi/departemen dengan departemen yang lain dan lingkungan organisasi mampu memancing para pegawai untuk bekerja dengan produktif. Lingkungan organisasi yang dapat bekerja sama serta suasana kerja yang aman dan nyaman akan mampu meningkatkan kinerja pegawai atas pekerjaan yang dilakukan dan memberikan kesan yang mendalam bagi pegawai yang pada akhirnya pegawai akan terus menghasilkan kinerja yang baik.

Di dalam kehidupan sehari-hari, di mana pun manusia berada, dibutuhkan peraturanperaturan dan ketentuan yang akan mengatur dan membatasi setiap kegiatan dan perilakunya. Namun peraturan-peraturan tersebut tidak akan ada artinya bila tidak disertai sanksi bagi manusia tersebut. Aktivitas dalam suatu instansi akan sangat membutuhkan ketaatan dari anggota-anggotanya pada peraturan dan ketentuan yang berlaku pada instansi tersebut. Dengan kata lain, disiplin kerja pada pegawai sangat dibutuhkan, karena apa yang menjadi tujuan instansi akan sukar dicapai bila tidak ada disiplin kerja. Dari pegawainya.Disiplin adalah sikap kesediaan dan kerelaan seseorang untuk mematuhi dan menaati norma-norma peraturan yang berlaku disekitarnya. Disiplin pegawai yang baik akan mempercepat tujuan perkantoran, sedangkan disiplin yang merosot akan menjadi penghalang dan memperlambat tujuan perkantoran. Disiplin yang baik mencermikan besarnya rasa tanggung jawab seseorang terhadap tugas-tugas yang diberikan kepadanya. Untuk memelihara dan meningkatkan kedisiplinan yang baik adalah hal yang sulit karena banyak faktor yang mempengaruhinya (Hasibuan, 2016:193).

Lingkungan organisasi merupakan bagian komponen yang sangat penting bagi pegawai dalam melakukan aktivitas kerja dengan memperhatikan lingkungan organisasi yang baik akan menciptakan kondisi dan suasana kerja yang mampu meningkatkan loyalitas kerja pegawai untuk bekerja sehingga membawa pengaruh terhadap kinerja pegawai dalam menghasilkan kinerja Pengertian lingkungan organisasi adalah segala sesuatu yang ada disekitar para pegawai dan yang dapat mempengaruhi dirinya dalam menjalankan tugas-tugas yang dibebankan (Sunyoto, 2012 : $65)$.

Loyalitas menurut kamus besar bahasa Indonesia artinya adalah patuh atau setia .menurut Agustian (,2008: 76) loyalitas adalah kesetiaan pada prinsip yang di anut sedangkan menurut Sudimin (2007 : 77) loyalitas berarti kesediaan karyawan dengan seluruh kemampuan, ketrampilan, pikiran dan waktu untuk ikut serta mencapai tujuan organisasi dan menyimpan rahasia organisasi serta tidak melakukan tindakan - tindakan yang merugikan perusahaan selama orang itu masih berstatus sebagai pegawai

Dinas kesehatan Kabupaten Aceh Tamiang merupakan salah satu instansi pemerintahan. Penulis mendapatkan beberapa masalah yang ada diorganisasi, adapun permasalahanpermasalahan yang tampak pada Dinas kesehatan Kabupaten Aceh Tamiang yang berhubungan dengan masalah disiplin masih ada pegawai yang tidak mentaatai peraturan yang sudah di tetapkan oleh Dinas Kesehatan Kabupaten Aceh Tamiang hal ini di karenakan sanksi tidak di berikan mengingat pengangkatan sebagai pegawai itu dilaksanakan dari pusat hal lain untuk lingkungan kerja masih ada yang belum dapat bekerja sama satu bagian dengan bagian lain terutama jika berhubungan dengan data sehingga perkerjaan yang di hasilkan berdasarkan perbidang bukan hasil kerja satu dinas yaitu Dinas Kesehatan kabupaten aceh tamiang. sehingga jika data sudah tidak bisa di dapat maka pekerjaan menjadi berlarut - larut untuk di selesaikan sehingga loyalitas kerja juga menjadi rendah sebab jika pegawai loyal maka apapun yang di kerjakan bukan untuk 
kepentingan bidang tetapi menjadi kepentingan satu instansi yaitu Dinas kesehatan Kabupaten Aceh Tamiang hal inilah yang mengakibatkan menjadi rendahnya kinerja pegawai yang belum sepenuhnya sesuai dengan target yang diharapkan oleh Dinas Kesehatan Kabupaten Aceh Tamiang.

Berdasarkan uraian diatas penulis tertarik untuk membahas masalah tentang arti penting Lingkungan Kerja dan Disiplin terhadap Kinerja Pegawai dan menuangkannya dalam bentuk karya ilmiah dengan judul: "Pengaruh Disiplin, Lingkungan Organisasi dan Loyalitas terhadap Kinerja Pegawai Dinas Kesehatan Kabupaten Aceh Tamiang “

Berdasarkan latar belakang yang dikemukan diatas, tujuan dari penelitian ini :

1. Untuk menganalisis pengaruh Disiplin Kerja terhadap Kinerja Pegawai di Dinas Kesehatan Kabupaten Aceh Tamiang

2. Untuk menganalisis pengaruh Lingkungan Organisasi terhadap Kinerja dan Disiplin Pegawai di Dinas Kesehatan Kabupaten Aceh Tamiang

3. Untuk menganalisis pengaruh Loyalitas Kerja terhadap Kinerja Pegawai di Dinas Kesehatan Kabupaten Aceh Tamiang

4. Untuk menganalisis pengaruh Disiplin, Lingkungan Organisasi dan Loyalitas kerja terhadap Kinerja Pegawai di Dinas Kesehatan Kabupaten Aceh Tamiang

\section{Metode Penelitian}

\subsection{Lokasi Penelitian}

Penelitian dilaksanakan di Kantor Dinas Kesehatan Kabupaten Aceh Tamiang Jalan Ir.Haji Juanda (Komplek Perkantoran Aceh Tamiang) Karang Baru Kabupaten Aceh Tamiang

\subsection{Populasi}

Populasi adalah wilayah generalisasi yang terdiri atas obyek/subjek yang mempunyai kuantitas dan karakteristik tertentu yang ditetapkan oleh peneliti untuk dipelajari dan kemudian ditarik kesimpulannya. Populasi pada penelitian ini merupakan seluruh pegawai di
Dinas Kesehatan Kabupaten Aceh Tamiang yang berjumlah 35 Orang.

\subsection{Sampel}

Sampel yang akan diambil dari populasi tersebut harus betul-betul representatif atau dapat mewakili. Dengan teknik penarikan sampel secara total sampling atau metode sensus, maka sampel dalam penelitian ini berjumlah 33 orang yang terdiri pada bidang bidang yang dianggap peneliti mempunyai konteribusi langsung pada variable yang di teliti

\subsection{Teknik Pengumpulan Data}

a. Studi Perpustakaan

Yaitu memperoleh data pendukung dalam penelitian ini berdasarkan pada buku-buku, karya ilmiah yang relevan terhadap penelitian

b. Mengadakan pengamatan langsung ke lokasi penelitian.

Pengamatan ini dilakukan untuk memperoleh gambaran suasana tempat kerja, proses kerja dan hal-hal lain yang diperlukan.

c. Kuisioner / Angket Penelitian.

Yaitu dengan cara memberikan kuesioner atau angket penelitian kepada ....... orang pegawai Dinas Kesehatan Kabupaten Aceh Tamiang, dengan berpedoman pada Skala Likert :

Tabel 1

Nilai Korelasi

\begin{tabular}{|c|l|c|}
\hline No & \multicolumn{1}{|l|}{ Keterangan / Jawaban } & $\begin{array}{c}\text { Bobot } \\
\text { Nilai }\end{array}$ \\
\hline 1 & Sangat Setuju (SS) & 5 \\
\hline 2 & Setuju (S) & 4 \\
\hline 3 & Kurang Setuju (KS) & 3 \\
\hline 4 & Tidak Setuju (TS) & 2 \\
\hline 5 & $\begin{array}{l}\text { Sangat Tidak Setuju } \\
\text { (STS) }\end{array}$ & 1 \\
\hline
\end{tabular}

Sumber : Sugiyono (2004:102)

\subsection{Definisi Operasional Variabel}

Definisi operasional variable pada penelitian ini dapat dilihat pada table 1 berikut : 
Tabel 2

Definisi Operasional Variabel

\begin{tabular}{|c|c|c|c|}
\hline No & Defenisi & Indikator Pengukuran & Variabel \\
\hline 1. & $\begin{array}{l}\text { Disiplin merupakanTindakan } \\
\text { manajemen untuk mendorong para } \\
\text { anggota organisasi memenuhi tuntutan } \\
\text { berbagai ketentuan tersebut,dan juga } \\
\text { untuk mencapai tujuan suatu } \\
\text { perusahaan. }\end{array}$ & $\begin{array}{l}\text { - Tingkat Kehadiran } \\
\text { - Tata Cara Kerja } \\
\text { - Ketaatan Pada } \\
\text { - Atasan } \\
\text { - Kesadaran } \\
\text { - Bekerja } \\
\text { - TanggungJawab (Agustini, } \\
\text { 2011: 73-74) }\end{array}$ & $\begin{array}{c}\text { Variabel } \\
\text { Bebas }\end{array}$ \\
\hline 2. & $\begin{array}{l}\text { Lingkungan Organisasi adalah suatu } \\
\text { proses mempengaruhi aktivitas } \\
\text { seseorang dan kelompok dalam rangka } \\
\text { pencapaian tujuan yang telah } \\
\text { ditentukan sebelumnya. } \\
\text { Wahjusumodjo }(2005: 21)\end{array}$ & $\begin{array}{l}\text { - Tipe/gaya kepemimpinan } \\
\text { - Keteladan } \\
\text { - Kehadiran } \\
\text { - Soritauladan }\end{array}$ & $\begin{array}{c}\text { Variabel } \\
\text { bebas }\end{array}$ \\
\hline 3. & $\begin{array}{l}\text { loyalitas sebagai sikap positif atau } \\
\text { negatif yang dilakukan individu } \\
\text { terhadap pekerjaan mereka. } \\
\text { Simamora (2006:134) }\end{array}$ & $\begin{array}{l}\text { - Jenis pekerjaan } \\
\text { - Kebebasan dan taunggung jawab } \\
\text { - Gaji/kompensasi } \\
\text { - Masukan rekan kerja } \\
\text { - Inisiatif }\end{array}$ & $\begin{array}{c}\text { Variabel } \\
\text { bebas }\end{array}$ \\
\hline 4. & $\begin{array}{l}\text { Kinerja SDM adalah prestasi kerja atau } \\
\text { hasil kerja (output) baik kualitas } \\
\text { maupun kuantitas yang dicapai SDM } \\
\text { persatuan periode waktu dalam } \\
\text { melaksanakan tugas kerjanya sesuai } \\
\text { dengan tanggung jawab yang diberikan } \\
\text { kepadanya. } \\
\text { (Sutrisno, 2013:118) }\end{array}$ & $\begin{array}{l}\text { - Efektif } \\
\text { - Efisien } \\
\text { - Kualitas } \\
\text { - Ketepatan waktu } \\
\text { - Produktivitas } \\
\text { - Keselamatan } \\
\quad \text { (Moeheriono, 2012: 114) }\end{array}$ & $\begin{array}{c}\text { Variabel } \\
\text { terikat }\end{array}$ \\
\hline
\end{tabular}

\subsection{Teknik Analisa Data}

Tehnik analisa data yang digunakan pada penelitian ini dikumpulkan dari dua sumber, yakni dilakukan dengan melakukan pengolahan data dengan beberapa uji yang dilakukan dengan uji validitas, uji reabilitas, uji asumsi klasik, uji regresi sampai dengan uji hipotesa yaitu uji f dan uji t serta determinasi.

\section{Analisis dan Pembahasan \\ 3.1. Analisis Regresi Berganda}

Dari Tabel 2 di bawah diperoleh model persamaan regresi berganda yang terbaik karena sudah memenuhi asumsi klasik sebagai berikut:

$$
Y=12.264+2.428 X_{1}+1.173 X_{2}+0.261 X_{3}
$$

Tabel 3

Koefisien Regresi Berganda Coefficients $^{a}$

\begin{tabular}{|l|r|r|r|r|r|}
\hline \multirow{2}{*}{ Model } & \multicolumn{2}{|c|}{ Unstandardized Coefficients } & \multicolumn{1}{c|}{$\begin{array}{c}\text { Standardized } \\
\text { Coefficients }\end{array}$} & \multirow{2}{*}{$\mathrm{t}$} & Sig. \\
\cline { 2 - 4 } & \multicolumn{1}{|c|}{$\mathrm{B}$} & Std. Error & \multicolumn{1}{|c|}{ Beta } & & .215 \\
\hline (Constant) & 12.264 & 10.534 & & & .831 \\
X1 & 2.428 & 1.050 & 2.266 & 2.312 & .000 \\
X2 & 1.773 & 1.040 & 1.658 & 1.706 & .000 \\
X3 & .261 & .147 & .262 & 1.769 & .000 \\
\hline
\end{tabular}

a. Dependent Variable: $Y$ 
Persamaan regresi linear berganda tersebut dapat diartikan sebagai berikut :

a. Jika variable Disiplin, Loyalitas, dan lingkungan organisasi 12,264 bernilai sama dengan nol, maka kinerja akan bernilai sebesar satuan dengan kecenderungan mengalami penurunan.

b. Jika variabel disiplin ditingkatkan sebesar 1 satuan, maka kinerja guru akan meningkat sebesar 2,428 satuan.

c. Jika Loyalitas ditingkatkan sebesar 1 satuan, maka akan diikuti dengan peningkatan kinerja guru sebesar 1,773 satuan.

d. Jika lingkungan organisasi dintingkatkan 1 satuaan, maka akan diikuti dengan peningkatan kinerja sebesar 0,261 satuan

\subsection{Uji Hipotesa \\ 3.2.1. Uji Parsial (Uji t)}

Pengujian hipotesis untuk uji t (uji partial) dilakukan untuk melihat pengaruh masingmasing variabel bebas terhadap variabel tidak bebas. Dari Tabel 3 dibawah diperoleh nilai $\mathrm{t}_{\text {hitung }}$ dari setiap variabel bebas dan kemudian dibandingkan dengan nilai $t_{\text {tabel }}$ yang dipertoleh dari tabel T.

Tabel 4

Hasil Uji t (Parsial)

Coefficients $^{\mathrm{a}}$

\begin{tabular}{|l|r|r|r|r|r|}
\hline \multirow{2}{*}{ Model } & \multicolumn{2}{|c|}{ Unstandardized Coefficients } & $\begin{array}{c}\text { Standardized } \\
\text { Coefficients }\end{array}$ & \multirow{2}{*}{$\mathrm{t}$} & \multirow{2}{*}{ Sig. } \\
\cline { 2 - 4 } & \multicolumn{1}{|c|}{$\mathrm{B}$} & Std. Error & \multicolumn{1}{c|}{ Beta } & & \\
\hline (Constant) & 12.046 & 12.332 & & 5.680 & .000 \\
X1 & .206 & .188 & .186 & 1.093 & .000 \\
X2 & .586 & .175 & .585 & .490 & .000 \\
X3 & .325 & .163 & .344 & 1.987 & .000 \\
\hline
\end{tabular}

a. Dependent Variable: Y

Nilai signifikansi dari Disiplin $\left(\mathrm{X}_{1}\right)$ adalah 0.000 nilai ini lebih kecil dari nilai alphanya yang sebesar 0.05. Dengan demikian dapat dinyatakan bahwa Disiplin memiliki pengaruh signifikanterhadap Kinerja. Selanjutnya diketahui bahwa nilai signifikansi dari lingkungan organisasi $\left(\mathrm{X}_{2}\right)$ adalah 0.000 nilai ini lebih kecil dari nilai alphanya yang sebesar 0.00 . Dengan demikian dapat dinyatakan bahwa lingkungan organisasi memiliki pengaruh signifikan terhadap Kinerja. Selanjutnya di ketahui bahwa nilai signifikansi loyalitas $\left(\mathrm{X}_{3}\right)$ adalah 0,00 nilai ini lebih kecil dari 0,05 dengan demikian loyalitas memiliki pengaruh yang signifikan terhadap Kinerja.

\subsubsection{Uji Simultan (Uji F)}

Uji serempak dilakukan untuk melihat tingkat signifikansi kedua variabel bebas secara bersama - sama berpengaruh terhadap variabel terikat. Hasil uji secara serempak dapat dilihat pada tabel dibawah ini :

Tabel 5.

Uji FANOVA $^{\mathrm{a}}$

\begin{tabular}{|l|r|r|r|r|r|}
\hline Model & \multicolumn{1}{|c|}{$\begin{array}{c}\text { Sum of } \\
\text { Squares }\end{array}$} & Df & Mean Square & F & Sig. \\
\hline Regression & 221.767 & 3 & 73.922 & 6.920 & $.001^{\mathrm{b}}$ \\
Residual & 320.469 & 30 & 10.682 & & \\
Total & 542.235 & 33 & & & \\
\hline
\end{tabular}

a. Dependent Variable: $Y$

b. Predictors: (Constant), X3, X2, X1

Tabel 4 diatas menunjukkan bahwa nilai signifikansi adalah sebesar 0.001. Nilai signifikansi tersebut lebih kecil dibandingkan dengan nilai Alpha sebesar 0.05. Sehingga dapat disimpulkan bahwa secara bersama sama Disiplin, Lingkungan Organisasi,

Loyalitas berpengaruh signifikan terhadap Kinerja.

\subsubsection{Koefisien Diterminasi $\left(\mathbf{R}^{2}\right)$}

Untuk dapat mengetahui besarnya Disiplin, Lingkungan Organisasi, Loyalitas berpengaruh 
signifikan terhadap Kinerja dapat dilihat pada tabel 5berikut

koefisien determinasinya yang berada pada

Tabel 6

Koefisien Diterminasi $\left(\mathrm{R}^{2}\right)$

\begin{tabular}{|l|r|r|r|c|}
\hline Model & R & R Square & $\begin{array}{c}\text { Adjusted R } \\
\text { Square }\end{array}$ & $\begin{array}{c}\text { Std. Error of the } \\
\text { Estimate }\end{array}$ \\
\hline 1 & $.640^{\mathrm{a}}$ & .409 & .350 & 3.26838 \\
\hline
\end{tabular}

Berdasarkan pada tabel 6 diketahui bahwa nilai R-Square adalah sebesar 0,409. Artinya bahwa Disiplin, Lingkungan Organisasi, Loyalitas berpengaruh signifikan terhadap Kinerja adalah sebesar $40.9 \%$ sisanya $59,1 \%$ dijelaskan oleh variabel lain yang tidak dimasukkan ke dalam model penelitian ini.

\section{Kesimpulan}

a. Disiplin berpengaruh signifikan terhadap Kinerja Pegawai di Dinas Kesehatan Kabupaten Aceh Tamiang dengan nilai signifikansi sebesar 0.000

b. Lingkungan Organisasi berpengaruh signifikan terhadap Kinerja Pegawai di Dinas Kesehatan Kabupaten Aceh Tamiang dengan nilai signifikansi sebesar 0.000

c. Loyalitas kerja berpengaruh signifikan terhadap Kinerja Pegawai di Dinas Kesehatan Kabupaten Aceh Tamiang dengan nilai signifikansi sebesar 0.000

d. Secara simultan, variable Disiplin, Lingkungan Organisasi, Loyalitas berpengaruh signifikan terhadap Kinerja dengan nilai signifikansi sebesar $0.001^{\mathrm{b}}$

\section{DAFTAR PUSTAKA}

AA. Anwar Prabu Mangkunegara, 2014, Manajemen Sumber Daya Manusia Perusahaan, PT. Remaja Rosdakarya, Bandung.

Aditya Nur Pratama (2015), Pengaruh Lingkungan Kerja Dan Disiplin Kerja Terhadap Kinerja Karyawan PT. Razer Brothers

Anggraini, D., \& Nuraini, H. (2016). Hubungan Persepsi Siswa Terhadap Kompetensi Pedagogik Guru dengan Hasil Belajar Biologi Siswa Kelas X SMA Swasta Sinar Husni Medan Tahun Pembelajaran 2014/2015. Jurnal Pelita Pendidikan,

Gibson, J. L., Ivancevich, dan J. H. Donelly, Jr. (2010). Organisasi: Perilaku, Struktur, Proses (Terjemahan). Edisi Kedelapan. Jakarta: Binarupa Aksara.
Handoko, 2011, Manajemen Personalia dan Sumber Daya Manusia, BPFE, Yogyakarta.

Hariandja, Marihot Tua Efendi. 2012. Manajemen Sumber Daya Manusia. Jakarta: Grasindo.

Hasibuan, Malayu S.P. 2016. Manajemen Sumber Daya Manusia. Edisi Revisi. Jakarta: Penerbit PT Bumi Aksara.

Malthis, 2012, Human Resource Management (edisi 10). Salemba Empat, Jakarta.

Rivai, Veithzal. 2011, Manajemen Sumber Daya Manusia untuk Perusahaan: dari Teori ke Praktik, Jakarta : RajaGrafindo Persada

Rowen (2017), Pengaruh Disiplin kerja dan Loyalitas Terhadap Kinerja Karyawan CV. Tirta Agung Jaya Mandiri

Sutrisno,Edi, 2013. Manajemen Sumber Daya Manusia, Cetakan Ketiga, Kencana Prenada Media Group, Jakarta.

Sedarmayanti, 2011, Sumber Daya Manusia dan Produktivitas Kerja, Mandar Maju, Bandung.

Simamora, Henry. 2009. Manajemen Sumber Daya Manusia. Yogyakarta: SIE YKPN.

Sugiyono. 2009, Metode Penelitian Bisnis, CV Alfabeta, Bandung.

Sugiyono.2014.Metode Penelitian Pendidikan Pendekatan Kuantitatif, Kualitati,f dan R\&D.Bandung:Alfabeta. _ _ 2010. Metode Penelitian Bisnis. Bandung: Alfabeta

Werther dan Darwis, 2010, Personnel Management and Human Resources, McGraw Hill Ltd, Tokyo 